\title{
Hobbes, Signification, and Insignificant Names
}

Stewart Duncan

ABSTRACT. The notion of signification is an important part of Hobbes's philosophy of language. It also has broader relevance, as Hobbes argues that key terms used by his opponents are insignificant. However Hobbes's talk about names' signification is puzzling, as he appears to have advocated conflicting views. This paper argues that Hobbes endorsed two different views of names' signification in two different contexts. When stating his theoretical views about signification, Hobbes claimed that names signify ideas. Elsewhere he talked as if words signified the things they named. Seeing this does not just resolve a puzzle about Hobbes's statements about signification. It also helps us to understand how Hobbes's arguments about insignificant speech work. With one important exception, they depend on the view that names signify things, not on Hobbes's stated theory that words signify ideas. The paper concludes by discussing whether arguments about insignificant speech can provide independent support for Hobbes's views about other issues, such as materialism.

KEYWORDS: Hobbes, signification, language, materialism

Language is an important topic for Hobbes. The workings of language are a vital part of $D e$ Corpore, the first part of his Elements of Philosophy. The account of language is central to his story about the workings of the mind, humans' linguistic abilities being for Hobbes what distinguish us mentally from other animals, enabling reasoning and understanding. Language plays an important role in his political philosophy too. ${ }^{1}$ In Hobbes's discussions of language, the notion of signification is key. It is a central semantic relation, playing the sort of role played in more recent accounts by meaning or sense or reference. It is unclear however what signification is. To signify is in some sense to be a sign, but a sign of what? ${ }^{2}$ Among the

${ }^{1}$ P. Pettit, Made with Words: Hobbes on Language, Mind, and Politics (Princeton: Princeton University Press, 2008).

2 I refer to discussions of Hobbes's views about names' signification throughout the paper. Several works discuss Hobbes's philosophy of language without focusing on names' signification: see among others D.H. Soles, Strong Wits and Spider Webs (Aldershot: Ashgate, 1996), the translator's notes to Thomas Hobbes, Part I of De Corpore, translated by A.P. Martinich (New York: Abaris Books, 1981), and T. Sorrel, Hobbes (London: Routledge, 
things that Hobbes says signify are names. Hobbes criticizes opponents for using names that are insignificant, and thus uses discussions of signification to defend his broader philosophical approach. Consider these comments in Leviathan.

All other names, are but insignificant sounds; and those of two sorts. One, when they are new, and yet their meaning not explained by definition; whereof there have been abundance coined by schoolmen, and puzzled philosophers.

Another, when men make a name of two names, whose significations are contradictory and inconsistent, as this name, an incorporeal body, or (which is all one) an incorporeal substance, and a great number more. ${ }^{3}$

Some names, Hobbes argues, are insignificant. A prominent example is 'incorporeal substance'. So Hobbes thinks there is something problematic about talk of incorporeal substances. Perhaps we even find here one of Hobbes's reasons for materialism. If talk of incorporeal substances is "absurd, insignificant, and nonsense", belief in them should apparently be avoided, if it is even possible. ${ }^{4}$

This paper addresses two main questions. First, what does Hobbes think that signification is, in particular the signification of names? Second, why does Hobbes think that some names are insignificant? If we could understand Hobbes's views about the signification of names, then we could understand his views about insignificant names, and thus be well placed to understand his arguments that certain names are insignificant. We would also have

1986). There are works on Hobbes's rhetoric, most notably D. Johnston, The Rhetoric of Leviathan (Princeton: Princeton University Press, 1989), and Q. Skinner, Reason and Rhetoric in the Philosophy of Hobbes (Cambridge: Cambridge University Press, 1996). Skinner's book also emphasizes the connection of Hobbes's work to Renaissance humanism. Work on the background to Locke's philosophy of language is also often useful: see E.J. Ashworth, “'Do Words Signify Ideas or Things?' The Scholastic Sources of Locke's Theory of Language" Journal of the History of Philosophy, 31 (1981), 299-326, and H. Dawson, Locke, Language, and Early-Modern Philosophy (Cambridge: Cambridge University Press, 2007).

${ }^{3}$ T. Hobbes, Leviathan, ed. E. Curley (Indianapolis: Hackett, 1994), I.IV, 16-7.

${ }^{4}$ Leviathan I.V, 19. 
addressed puzzling issues in Hobbes's philosophy of language, the literature on which is rightly described as exhibiting "something approaching maximal disagreement". 5

\section{Four views about name signification}

'Name' is a technical term. Hobbes seems to count all nouns and adjectives as names. In chapter 5 of the Elements of Law, he gives 'Socrates', 'Homer', 'man', 'just', 'valiant', 'strong', 'comely', and 'faith' as examples. 'Is', however, is consistently said not to be a name. 'Signification' is also a technical term. It has a long history in medieval discussions of language. ${ }^{6}$ In exploring such discussions, it is sensible not to assume that the notion of signification is the same as that of meaning, or some other current notion. That also applies in reading Hobbes. In Hobbes's case there is the further complication that he discusses the meaning as well as the signification of names. We need to consider what his views about signification are, and what his views about meaning are, while being careful not to mix them up. With that in mind, I turn to four possible understandings of Hobbes's view of the signification of names. As an example, I use a proper name, 'Emily'.

(1) The object view. 'Emily' signifies Emily.

On this view, the signification of a name is the object that it names or refers to. Hobbes often uses 'signify' in this way. Thus he says that "By miracles are signified the admirable works of God; and therefore, they are also called wonders". 7 The works themselves are said to be signified, not, say, our ideas of them. There are however reasons to doubt the object reading. In De Corpore, where Hobbes gives his fullest treatment of

\footnotetext{
5 D. Hanson, “Thomas Hobbes on 'Discourse' in Politics" Polity 24 (1991) 199-226, quoting 201.

${ }^{6}$ For an introduction to such theories, see L. M. de Rijk, "The Origins of the Theory of the Properties of Terms" in N. Kretzmann, A. Kenny, and J. Pinborg (ed.), The Cambridge History of Later Medieval Philosophy (Cambridge: Cambridge University Press, 1982) 16173; P.V. Spade, "The Semantics of Terms" in Kretzmann et al (ed.), 188-196; and S. Read, "Medieval Theories: Properties of Terms" in Edward N. Zalta (ed.), The Stanford Encyclopedia of Philosophy (Fall 2008 Edition), URL = $<$ http://plato.stanford.edu/archives/fall2008/entries/medieval-terms/>.

${ }^{7}$ Leviathan III.XXXVII, 233.
} 
language, he distinguishes two relations: naming and signifying. ${ }^{8}$ This counts against the object view: why distinguish signification from naming if signification is naming?

A second candidate for the signification of 'Emily' is the idea of Emily. ${ }^{9}$

(2) The idea view. 'Emily' signifies the (speaker's) idea of Emily.

There is textual support for this, as when Hobbes says that "all names are imposed to signify our conceptions", but also reasons against. ${ }^{10}$ Some passages suggest the object view. Others emphasize the signification of larger units - sentences, propositions, or utterances - to the extent that one might take Hobbes to think that these are in fact the only units that signify. ${ }^{11}$ Hobbes says "names in themselves are individual marks, for they recall thoughts even alone, while they are not signs except insofar as they are arranged in speech and are its parts". ${ }^{12}$ This suggests that names do not signify. Thus we have a third view.

(3) The nothing view. 'Emily' does not signify anything, because names are not the sort of things that signify.

\footnotetext{
${ }^{8}$ The seventeenth-century English version of De Corpore muddles the distinction. See I.C. Hungerland and G.R. Vick, "Hobbes's Theory of Signification" Journal of the History of Philosophy 11 (1973) 459-82, and their "Hobbes's Theory of Language, Speech, and Reasoning" in Hobbes, Part I of De Corpore, 9-169. For criticism of their approach, see G.M. Ross, "Hobbes's Two Theories of Meaning" in G. Cantor et al (ed.) The Figural and the Literal: Problems of Language in the History of Philosophy, Science and Literature, 1600-1800 (Manchester: Manchester University Press, 1987), 31-57.

${ }^{9}$ I use 'idea' where Hobbes uses various terms: 'idea', 'conception', 'phantasm', etc. Though there are distinctions between different sorts of idea Hobbes discusses, he appears not to use the differences in terminology to mark the distinctions in a regular way. For more on Hobbes's treatment of such terms, see W. Sacksteder, "Hobbes: Teaching Philosophy to Speak English", Journal of the History of Philosophy, 16 (1978), 33-45.

${ }^{10}$ Leviathan I.IV, 17.

${ }^{11}$ The distinctions between sentences, propositions, and utterances, and Hobbes's views about those distinctions, do not significantly affect the issues in this paper, about names. 12 Thomas Hobbes, De Corpore. Elementorum Philosopiae Sectio Prima, ed. K. Schuhmann. (Vrin: Paris, 2000), I.2.3. In quoting De Corpore I use the translation of chapters 1-6 in Hobbes, Part I of De Corpore and my own translations of passages from later chapters.
} 
Alternatively, one might take Hobbes to think that, though sentences are the things that primarily signify, there is a secondary sense in which names signify. One possible such view is this.

(4) The secondary idea signification view. No name signifies per se, as a name is not an act of communication. However, when a name is in a sentence, it contributes the idea to which it is related to the overall signification of the sentence. Thus, the name can be said to signify that idea. ${ }^{13}$

There is a range of possible views about the signification of names. By implication, there is a range of possible views about insignificant names. On the object view, a name is insignificant if it names no object. On the idea view (or the secondary idea signification view) an insignificant name would lack an appropriate connection to an idea in the speaker's mind. On the nothing view, all names lack signification, so it is hard to see how any name could be distinctively insignificant.

\section{Strategies for investigating the issue}

Signification was a notion with a long history. One might hope to to find out what Hobbes thought signification was by seeing what the tradition thought signification was. This sounds promising, but there are good reasons to think it will not work.

First and most importantly, an key dispute within the tradition matches up with disputes about what view Hobbes had. Signification was discussed by medieval theorists of the properties of terms. They disagreed about what was signified by a categorematic term: a thing or a concept. We find Lambert of Auxerre writing in the thirteenth century that

The signification of a term is the concept of a thing, a concept on which an utterance is imposed by the will of the person instituting the term. For, as Aristotle maintains in the first book of De interpretatione (16a3-5), utterances

\footnotetext{
${ }^{13}$ See M. Pécharman, "Sémantique et doctrine de la proposition: Hobbes inconciliable avec la tradition terministe?" in R.L. Friedman and S. Ebbesen (ed.), John Buridan and Beyond: Topics in the Language Sciences, 1300-1700 (Copenhagen: Royal Danish Academy of Sciences and Letters, 2004) 203-36, especially 211-3.
} 
are signs of states in the soul - i.e., in the understanding - but concepts are the signs of things. ${ }^{14}$

The debate goes back to Aristotle, or at least to Boethius's understanding of Aristotle. Some took Lambert's line, that the correct and genuinely Aristotelian position was that terms signify concepts, but others held that terms signify things. Ockham said that "spoken words are used to signify the very things that are signified by concepts of the mind". ${ }^{15}$ That is, words do not signify concepts: both words and concepts signify things. This debate continued, the same question being debated by sixteenth-century logicians. ${ }^{16}$ The debate mirrors the difference between object and idea readings of Hobbes. So even if we can associate Hobbes with this tradition, we can hardly expect to discover from that association what Hobbes thought signification was. ${ }^{17}$

Secondly, making connections between Hobbes and that tradition is complicated by our lack of detailed knowledge of Hobbes's reading, either while he was a student at Oxford or in the years between then and his composition of his work on the philosophy of language. Thirdly, even if we could solve those problems, we would still have to deal with the fact that Hobbes was happy to redefine established terminology in his own way. His use of the language of natural law is perhaps the most prominent example, but he did this more widely. ${ }^{18}$ Overall, though there is an interesting question of how Hobbes's views about language connect to earlier views, examining those earlier views is not a promising way to resolve the issue of Hobbes's view of signification. For that, we must focus on Hobbes's texts.

\footnotetext{
${ }^{14}$ N. Kretzmann and E. Stump, The Cambridge Translations of Medieval Philosophical texts, Volume One, Logic and the Philosophy of Language (Cambridge: Cambridge University Press, 1988), 104.

${ }^{15}$ William of Ockham, Ockham's Theory of Terms: Part I of the Summa Logicae, translated by M.J. Loux (South Bend: St Augustine's Press, 1998), 50.

${ }^{16}$ See Ashworth, "Do Words Signify Ideas or Things?" and her "Jacobus Naveros (fl. ca. 1533) on the Question: 'Do Spoken Words Signify Concepts or Things?'” in L.M. de Rijk and A.G. Braackuis (ed.), Logos and Pragma: Essays on the Philosophy of Language in Honour of Professor Gabriel Nuchelmans (Nijmegen: Ingenium, 1987), 189-214.

${ }^{17}$ For discussion of Hobbes's relation to that tradition, see Pécharman, "Sémantique et doctrine de la proposition".

${ }^{18}$ Pettit, Made with Words, 53-4.
} 


\section{The Elements of Law (1640)}

The Elements of Law was Hobbes's first systematic philosophical work. It begins with an account of individual humans and their minds, working towards an account of groups of humans, and thus of political philosophy. Here as elsewhere, Hobbes thinks an account of the workings of language is an essential part of an account of the workings of the mind. For Hobbes, the ability to use language is one of the key differences between humans and other animals. It also enables further abilities, such as the ability to reason about causes and consequences in a way that moves beyond the simple forming of associations from one's own experience.

Hobbes devotes chapter 5 to his basic account of language. He describes the role of names as marks, reminders for the individual who uses the name. This use of language is much like the use of non-linguistic marks: Hobbes uses the example of a mark set up to help one remember a rock at sea. Names, as marks, stand in at least two important relationships, naming (the things they name) and reminding (the user of the things they name). Meanwhile, "[t]hings named, are either the objects themselves, as man; or the conception itself that we have of man, as shape or motion; or some privation [e.g., when we call someone unjust]". ${ }^{19}$ This introduces names, and the naming relation, but says nothing about signification.

There is no systematic treatment of signification in this chapter, though it is mentioned when Hobbes discusses equivocation.

The appellations that be universal, and common to many things, are not always given to all the particulars, (as they ought to be) for like conceptions and considerations in them all; which is the cause that many of them are not of constant signification, but bring into our minds other thoughts than those for which they were ordained. And these are called EQUIVOCAL. As for example, the word faith sometimes signifieth the same with belief; sometimes it signifieth particularly that belief which maketh a Christian; and sometimes it signifieth the keeping of a promise. ${ }^{20}$

Here we have a word that can signify beliefs, and can signify actions (such as the keeping of promises). There is also talk of the conceptions involved. But though words are said to be

\footnotetext{
${ }^{19}$ EL 5.2-3.

${ }^{20}$ EL 5.7.
} 
"ordained for" thoughts, and to be "given to" particulars "for" conceptions, they are not said to signify those thoughts or conceptions. So the text suggests the object view of name signification.

Chapter 6 presents a view about the meaning of names: "the truth of a proposition is never evident, until we conceive the meaning of the words or terms whereof it consisteth, which are always conceptions of the mind". ${ }^{21}$ That is, words name ideas. That reading is supported by a later passage: "by all names we ought to have some meaning and conception". ${ }^{22}$ However, when we look at Hobbes's uses of 'meaning' elsewhere in the Elements of Law, the picture becomes less clear. Consider this from chapter 9: "COURAGE, in a large signification, is the absence of fear in the presence of any evil whatsoever; but in a stricter and more common meaning, it is contempt of wounds and death, when they oppose a man in the way to his end". ${ }^{23}$ This is notable because it uses 'meaning' and 'signification' interchangeably, and also because it embodies an object view of meaning and signification. The relevant passages in the Elements of Law appear then to be muddled.

\section{Other texts of the $1640 \mathrm{~s}$}

De Cive lacks a theoretical discussion of signification, but the relevant terms are used.

Hobbes talks as if he held an object theory of name signification. Thus he talks about "the very word Justice, (wich signifies a steady will of giving every one his Owne)", ${ }^{24}$ says that "Neither by the word Right is any thing else signified, then that liberty which every man hath to make use of his naturall faculties according to right reason". ${ }^{25}$

Hobbes proposed a theory of the signification of names when he wrote a draft of $D e$ Corpore, as is evidenced by Chatsworth manuscript A.10. Jacquot and Jones describe this

\footnotetext{
${ }^{21}$ EL 6.4.

${ }^{22}$ EL 11.1.

${ }^{23}$ EL 9.4 .

${ }^{24}$ T. Hobbes, De Cive. English Version, ed. Howard Warrender (Oxford: Clarendon, 1983), 27. I quote the English version, but we see the equivalent use of 'significare' in the Latin version: De Cive. Latin Version, ed. H. Warrender (Oxford: Clarendon, 1983), 75. There is some dispute about how reliable the seventeenth-century English version of De Cive, published by Warrender, is. But even if it should be completely ignored, my point is still supported by the Latin text.

${ }^{25}$ De Cive. English Version 47. Again we see the equivalent use of 'significare' in the Latin text, Latin Version 94.
} 
manuscript as notes of Hobbes's for De Corpore, but Noel Malcolm argues it is in fact Robert Payne's notes on Hobbes's work. ${ }^{26}$ Even if Malcolm is right, this text still provides evidence about Hobbes's view of name signification in the 1640s: if the text is not by Hobbes, it is Payne writing about Hobbes. It tells us that "Names are therefore signs of concepts, not of things. Every name refers to some thing named." 27 The view is clear: names name objects and are signs of concepts. If we take this together with the claims of the Elements of Law, an overall picture starts to emerge from the texts of the 1640s.

There are two contexts in which Hobbes talks about signification and meaning: those in which he states his theory of signification and meaning, and those in which he talks about the meaning and signification of particular words. In the first context Hobbes states an idea theory, but his use of 'signification' elsewhere accords with an object theory. The evidence for that pattern is not overwhelmingly strong, for Hobbes said little about the topic in the 1640s, and the manuscript A.10 plausibly contains a text about Hobbes's views rather than Hobbes's own statement of them. ${ }^{28}$ Hobbes said much more in the 1650 s though, and the pattern recurred.

\section{Leviathan (1651)}

Chapter 4 of Leviathan has the same role as chapter 5 of the Elements of Law: here Hobbes states his views about the uses and properties of language. Again Hobbes introduces names as marks. But he also presents a second use of names, as signs, which signify.

Signification first appears as something done by things other than names. "So that the first use of names is to serve for marks, or notes of remembrance. Another is when many use the same words, to signify (by their connexion and order) one to another, what they conceive

\footnotetext{
${ }^{26}$ N. Malcolm, Aspects of Hobbes (Oxford: Clarendon, 2002), 99-101.

27 "Sunt ergo nomina signa conceptuum, non rerum. Nomen omne ad nominatum aliquid refertur'. T. Hobbes, Critique du 'De Mundo' de Thomas White, ed. J. Jacquot and H.W. Jones (Paris: Vrin-CNRS, 1973), 464. The editors discuss the text at 78-80.

${ }^{28}$ In Hobbes's objections to Descartes's Meditations, he talks once of signification, but of the signification of a proposition (OL 5.272). He also talks of the "names of things" being combined in accordance with "arbitrary conventions we have laid down in respect of their meaning" (OL 5.257-8). I quote the translation in The Philosophical Writings of Descartes, ed. J. Cottingham, R. Stoothoff, and D. Murdoch (Cambridge: Cambridge University Press, 1984), 2.125-6. Though that passage tells us that the meaning of names is related to their use, it does not say how.
} 
or think of each matter". ${ }^{29}$ Hobbes talks about names, but the thing that is signifying includes not just names but also their "connexion and order". That is, some larger unit, such as a sentence, is involved. However, Hobbes also discusses the signification of names, suggesting at first that names signify the things they name.

When two names are joined together into a consequence or affirmation (as thus, a man is a living creature, or thus, if he be a man, he is a living creature), if the latter name, living creature, signify all that the former name, man, signifieth, then the affirmation or consequence is true; otherwise false. ${ }^{30}$ The natural reading of this is as concerned with the objects named by 'living creature' and 'man'. If everything named by 'man' is also among the things named by 'living creature', then 'a man is a living creature' is true. So this talk about what a name signifies appears to be talk about what it names. But there is a problem with this approach. Later in the chapter, Hobbes says that "all names are imposed to signify our conceptions". ${ }^{31}$ This appears to state the idea view rather than the object view. One could try to read it as compatible with the object view, as 'all names are imposed (naming and signifying objects) so that they can be used to make utterances that signify our thoughts', but Hobbes would have chosen a very odd way to say that.

We seem to face a puzzle. Some texts point to 'Emily' signifying Emily and not the idea of Emily, and others to 'Emily' signifying the idea of Emily and not Emily. ${ }^{32}$ However, the shifts are not random. There are places where Hobbes is explicitly stating a view about the signification of names. When he does that, he favours an idea view. However, there are other places where Hobbes talks about what particular names signify and there he talks as if he held an object theory of name signification.

\footnotetext{
${ }^{29}$ Leviathan I.V, 13.

${ }^{30}$ Leviathan I.V, 14-5.

${ }^{31}$ Leviathan I.V, 17.

32 J.S. Mill, A System of Logic, ed. J.M. Robson (Toronto: University of Toronto Press) 24, notes something like this puzzle. Perhaps it also lies behind Martin's view that "Hobbes is primarily concerned with denotation or naming and not with meaning or intension. (In fact, it is not clear that he is aware of the distinction.)" R.M. Martin, "On the Semantics of Hobbes" Philosophy and Phenomenological Research 14 (1953), 205-11, quoting 205.
} 
Further evidence that Hobbes uses 'signify' in these two ways in these two contexts comes from other parts of Leviathan. ${ }^{33}$ Hobbes many times uses 'signify' for a relation between a word and an object or action signified. Consider these examples from the chapters in Part III in which Hobbes looks at the signification of various terms in scripture. ${ }^{34}$

The word body, in the most general acceptation, signifieth that which filleth or occupieth some certain room or imagined place. ${ }^{35}$

I find the KINGDOM OF GOD to signify, in most places of Scripture, $a$ kingdom properly so named. ${ }^{36}$

Where there is mention of the Word of God or of man, it doth not signify a part of speech, such as grammarians call a noun, or a verb, or any simple voice without a contexture with other words to make it significative, but a perfect speech or discourse whereby the speaker affirmeth, denieth, commandeth, promiseth, threateneth, wisheth, or interrogateth. ${ }^{37}$

By miracles are signified the admirable works of God; and therefore, they are also called wonders. ${ }^{38}$

The word Church (Ecclesia) signifieth in the books of Holy Scripture divers things. Sometimes ... God's house, that is to say, for a temple wherein Christians assemble to perform holy duties publically... [sometimes] a congregation or an assembly of citizens, called forth to hear the magistrate speak unto them ... [and sometimes] the men that have right to be of the congregation, though not actually assembled. ${ }^{39}$

In each case a word is said to signify the thing named, not the idea of it. Hobbes systematically uses 'signify' in this way throughout Leviathan.

\footnotetext{
${ }^{33}$ I focus again on talk about the signification of names, and omit talk about the signification of utterances and non-linguistic acts, and uses of 'signify' for a translation relation.

${ }^{34}$ This is not to say, of course, that we only find such passages in Part III: I have already cited some from elsewhere.

${ }^{35}$ Leviathan III.XXXIV, 207.

${ }^{36}$ Leviathan III.XXXV, 216.

${ }^{37}$ Leviathan III.XXXVI, 222.

${ }^{38}$ Leviathan III.XXXVII, 233.

${ }^{39}$ Leviathan III.XXXIX, 247.
} 
In Leviathan as in the Elements of Law, Hobbes talks about the meaning of terms as well as their signification. Here too Hobbes treats talk of the meaning of a name as interchangeable with talk of its signification. That is strongly evidenced by a passage from the start of chapter XXXIV.

Seeing the foundation of all true ratiocination is the constant signification of words, which in the doctrine following, dependeth not (as in natural science) on the will of the writer, nor (as in common conversation) on vulgar use, but on the sense they carry in the Scripture, it is necessary, before I proceed any further, to determine, out of the Bible, the meaning of such words as by their ambiguity, may render what I am to infer upon them obscure or disputable. ${ }^{40}$ One might perhaps investigate whether terms have a constant signification by investigating whether they have a constant meaning, where meaning is some property of words distinct from their signification. But it is much more plausible (especially given the absence of a theory of meaning so called in Leviathan) that Hobbes uses 'meaning' as interchangeable with 'signification' here.

\section{De Corpore (1655)}

Hobbes's standard use of 'signify' in Leviathan fits the object view. But his stated theory in the 1651 text is unclear. Is it simple idea theory, as suggested by Leviathan I.IV, or something else, as suggested by Leviathan III.XXXVI, where a word alone is said to lack that "contexture with other words" that could "make it significative"? This relates to the discussion of name signification in De Corpore, which takes the second approach.

Chapter 2 of De Corpore concerns words, principally names. As in Leviathan, Hobbes discusses names as marks and signs. Signifying is what signs do. But how do names signify?

Moreover, names in themselves are individual marks, for they recall thoughts even alone, while they are not signs except insofar as they are arranged in speech and are its parts. ${ }^{41}$

\footnotetext{
${ }^{40}$ Leviathan III.XXXIV, 207.

${ }^{41}$ De Corpore, I.2.3.
} 
This suggests that names do not signify anything, as only utterances signify. But Hobbes also says this.

Since, as has been defined, names ordered in speech are signs of conceptions, it is obvious that they are not signs of things themselves; for in what sense can the sound of the vocal sound "stone" be understood to be a sign of a stone, other than that whoever might have heard this vocal sound will gather that the speaker has thought of a stone? Therefore the dispute over whether names signify matter, form, or a composite of them and other disputes of this kind are characteristic of erring metaphysicians who do not understand the words about which they are arguing". 42

Here we see again the thought that a name alone is not a sign, but can be part of something that is a sign. In the context of that expression, the name is a sort of sign: thus Hobbes's comments about gathering that the speaker has thought of a stone. Hobbes does not here endorse a straightforward idea theory of signification, and there is some sense for him in which names do not signify anything. However, there is a secondary sense in which they do, and that involves a relationship between the name and a thought of the thing named. So we have something like the secondary idea signification view.

\section{Intermediate conclusions}

All four readings of Hobbes introduced earlier are right about some passages. Hobbes talks sometimes as if names signify objects (the object view) but at other times as if names signify ideas of those objects (the idea view). In yet other places he says that names alone do not signify (the nothing view) but he also appears to allow a secondary sense in which names do signify (the secondary idea signification view). The key to finding this something other than a muddle is that there is a pattern to which texts each correctly describes.

There are two contexts in which Hobbes uses the language of name signification. In the first, Hobbes states his theory of name signification. In the second, he uses the language of signification, but does not state his theory of it. In this second context, Hobbes consistently talks as if an object theory of name signification were correct. We have seen this in a variety of texts from the $1640 \mathrm{~s}$ and $1650 \mathrm{~s}$. Hobbes continued to write this way, as when he talked in

${ }^{42}$ De Corpore, I.2.5. 
his 1662 Answer to Bramhall about how "the generality of men speak the words of their masters by rote, without having any ideas of the things, which the words signify". 43

When stating his views about signification, Hobbes talked differently. He denied that names signify objects, preferring variants of the view that names signify ideas. The texts of the 1640s suggest that Hobbes then held a straightforward idea theory of signification. By De Corpore, and perhaps already by Leviathan, Hobbes held a secondary idea signification theory, on which names are only said to signify ideas in the context of a sentence. Consistently though, Hobbes's theory was on one side of the debate over whether words signify ideas or things, while his usage of 'signify' was on the other. ${ }^{44}$

With that in mind, I turn to Hobbes's arguments about the insignificant speech of his opponents. I focus on Leviathan, where such arguments are prominent, but begin with a related argument from the Elements of Law.

\section{An "absurdity of speech"}

In chapter 11 of the Elements of Law, Hobbes asks what thoughts we have related to certain words, such as 'God, 'angel', and 'spirit'. ${ }^{45}$ The following passage discusses views about souls.

And it is a plain contradiction in natural discourse, to say of the soul of man, that it is tota in toto, and: tota in quadlibet parte corporis, grounded neither upon reason nor revelation; but proceeding from the ignorance of what those things are which are called spectra, images that appear in the dark to children, and such as have strong fears, and other strong imaginations, as hath been said chap. 3, sect. 5, where I call them phantasms. For taking them to be things really without us, like bodies, and seeing them to come and vanish as

\footnotetext{
${ }^{43}$ EW 4.303-4.

${ }^{44}$ One might propose unifying these two aspects of Hobbes's talk about signification by attributing to him a Lockean view, on which words primarily and immediately signify ideas, but secondarily and mediately signify things. However, there is no sign of the distinction between immediate and mediate signification in Hobbes's texts.

${ }^{45}$ One might take this project to suggest an idea theory of signification, but Hobbes does not make the connection, and thoughts can be related to names without being signified by them.
} 
strangely as they do, unlike to bodies; what could they call them else, but incorporeal bodies? which is not a name, but an absurdity of speech. ${ }^{46}$

The problem arises, Hobbes says, from mistaken beliefs about spectra: believing them to be external things rather than thoughts. If you believe that, says Hobbes, then you must believe that these things resemble bodies in some ways (existing outside and independently of us) but not others (popping in and out of existence, or at least moving in odd discontinuous ways). Those beliefs, Hobbes further suggests, push one to the position in which the sensible name to give these things is 'incorporeal bodies': 'bodies' for their independent external existence, and 'incorporeal' for their weird behaviour, totally unlike bodies in other respects. And 'incorporeal body', as Hobbes concludes, is an absurd thing to call anything.

This is reminiscent of the argument from Leviathan 4 with which I began the paper, but is not, as we will see, really the same. Note though that the problems with the name are secondary. They are important for Hobbes because they are symptomatic of another problem, believing spectra to be like and unlike bodies, which is itself a sign of the basic problem, thinking them to be independently existing things rather than thoughts. The criticism is ultimately expressed as about language, but the linguistic problem is derivative of a more basic one.

\section{IX. "All other names are but insignificant sounds"}

Returning to the argument in Leviathan 4, we have this.

All other names are but insignificant sounds; and those of two sorts. One when they are new, and yet their meaning not explained by definition; whereof there have been abundance coined by schoolmen, and puzzled philosophers.

Another, when men make a name of two names, whose significations are contradictory and inconsistent, as this name, an incorporeal body, or (which is all one) an incorporeal substance, and a great number more. For whensoever any affirmation is false, the two names of which it is composed, put together and made one, signify nothing at all. For example if it be a false

\footnotetext{
${ }^{46}$ T. Hobbes, The Elements of Law: Natural and politic, ed. with a preface by F. Tönnies (London: Simpkin, Marshall, and Co, 1889), 11.5
} 
affirmation to say a quadrangle is round, the word round quadrangle signifies nothing, but is a mere sound. So likewise, if it be false, to say that virtue can be poured, or blown up and down, the words in-poured virtue, in-blown virtue, are as absurd and insignificant as a round quadrangle. ${ }^{47}$

Here is an argument for the insignificance of certain names: if 'Some $\mathrm{S}$ is $\mathrm{P}$ ' is false, then 'PS' is an insignificant name. 'A quadrangle is round' is false, so 'round quadrangle' is insignificant. 'Virtue is in-blown' is false so 'in-blown virtue' is insignificant. Similarly, says Hobbes, 'a body is incorporeal' and 'a substance is incorporeal' are false, so 'incorporeal body' and 'incorporeal substance' are insignificant. Taking Hobbes to be using 'signify' he usually does, following an object theory, this all adds up nicely. If 'Some S is $\mathrm{P}$ ' is false, then there is no thing that is named by both ' $\mathrm{S}$ ' and ' $\mathrm{P}$ '. So the compound name 'PS' will name no object. Because Hobbes uses 'signifies' for 'names', it signifies no object. That is, it's insignificant.

Descriptions such as 'senseless' and 'absurd' might suggest there is more wrong with these terms than their merely naming no actual thing. Consider 'winged horse', which names no actual thing: 'some horse is winged' is false. The name appears not to be completely senseless though. But in Hobbes's terms it is, unless perhaps it signifies the imagined figure of a winged horse. ${ }^{48}$ This is confirmed by a passage in the next chapter: "But when we reason in words of general signification, and fall upon a general inference which is false, though it be commonly called error, it is indeed an ABSURDITY, or senseless Speech". ${ }^{49}$ Hobbes here confirms that some things others call false, he calls absurd and senseless.

The argument in chapter 4 is supplemented by one in chapter 34 . Hobbes us what 'body' signifies - "that which filleth or occupieth some certain room or imagined place, and dependeth not on the imagination, but is a real part of that we call the universe" - and what 'substance' signifies - "The same also, because bodies are subject to change ... is called substance (that is to say, subject to various accidents), as: sometimes to be moved, sometimes to stand still [etc]". He then offers an argument against 'incorporeal substance': "according to this acceptation of the word, substance and body signify the same thing; and

\footnotetext{
${ }^{47}$ Leviathan I.IV, 17.

${ }^{48}$ Though the objects named by names are not always ideas, they can be ideas. The name 'my idea of Emily' names an idea of a cat, not a cat.

${ }^{49}$ Leviathan I.V, 19.
} 
therefore substance incorporeal are words which, when they are joined together, destroy one another, as if a man should say, an incorporeal body". ${ }^{50}$ Hobbes's argument appears to be the following. (1) 'Body' and 'substance' signify the same thing. So (2) 'incorporeal substance' is equivalent to 'incorporeal body'. But (3) 'incorporeal body' is unacceptable. So (4) 'incorporeal substance' is unacceptable. The use of 'signify the same thing' looks to be another case of Hobbes's use of 'signify' as if he believed in an object theory. Then however the move from (1) to (2) looks questionable, because it relies on two names being substitutable because of their extensional equivalence alone. ${ }^{51}$ That is not obviously a good idea, but it is what Hobbes is doing.

If Hobbes's argument begins from knowledge of the extensional equivalence of 'substance' and 'body', then it begins from materialism being true about the actual world. So the claims about the unacceptability of 'incorporeal substance', if grounded on this argument alone, appear unlikely to persuade any actual opponents. This is true in general of these arguments from chapters 4 and 36: they rely on claims that appear so contentious that it is hard to understand how Hobbes could have thought anyone would have been persuaded by arguments based on them. ${ }^{52}$ We can make sense of this if we think of these arguments about insignificant names as being like the argument about spectra in the Elements of Law, where what's presented as an argument about language is fundamentally driven by non-semantic, non-linguistic issues. The use of the language of signification in these passages has more the character of a rhetorical flourish, than of the giving of independent reasons. Still, there is another important passage in Leviathan about the absence of signification, where the argument is rather different.

\section{Leviathan 5}

But when we make a general assertion, unless it be a true one, the possibility of it is inconceivable. And words whereby we conceive nothing but the sound

\footnotetext{
${ }^{50}$ Leviathan III.XXXIV, 207.

${ }^{51}$ Hobbes sees non-extensional differences between the terms, as they are applied to the same stuff for different reasons. 'Body' is applied when we're thinking of it as mindindependent extended stuff, 'substance' when we're thinking of it as the subject of accidents. ${ }^{52}$ As I discuss below, one might well suspect that some of Hobbes's arguments are circular: that he argues for instance from the truth of materialism to the insignificance of 'immaterial substance' to the truth of materialism.
} 
are those we call absurd, insignificant, and nonsense. And therefore if a man should talk to me of a round quadrangle, or accidents of bread in cheese; or immaterial substances, or of a free subject; a free will, or any free, but free from being hindered by opposition, I should not say he were in an error; but that his words were without meaning; that is to say, absurd. ${ }^{53}$

Here names are said to be insignificant when an appropriate conception is absent. 'Round quadrangle' is insignificant because there is no accompanying idea of a round quadrangle. Thus Hobbes here relies on an idea theory of name signification. ${ }^{54}$ Goodness knows why an idea theory is employed here all of a sudden. However, having seen that Hobbes in general seems happy to employ two conflicting theories of name signification, it becomes less surprising than it would otherwise be that there should be two different views of signification involved in passages about insignificant names. This reduces the pressure to twist this passage to fit into the same framework as the two discussed above: it just does not, because Hobbes was inconsistent in how he spoke about the signification of names. ${ }^{55}$ There is a pattern to Hobbes's inconsistencies, but that doesn't make them consistent or justified. ${ }^{56}$

The reasons why the names listed are insignificant need more explanation, based on what Hobbes says elsewhere. In the case of 'immaterial substance', the necessary further detail is provided by the equation of 'immaterial substance' with 'immaterial body'. Though an immaterial substance may seem to be conceivable, an immaterial body is not. But if we

\footnotetext{
${ }^{53}$ Leviathan I.V, 19.

${ }^{54}$ One might say the same about the discussion in Leviathan I.VIII of "words without anything correspondent to them in the mind". However, that discussion is about "when men speak such words as, put together, have in them no signification at all", but not about compound names, and thus appears to be about insignificant sentences, not insignificant names.

${ }^{55}$ In Leviathan I.IV we see another argument about language that's problematic because of the absence of certain conceptions, concluding that "of absurd and false affirmations, in case they be universal, there can be no understanding" (Leviathan I.IV, 17). But that is a passage about knowledge and understanding, not signification and meaning. Unlike the passage in the following chapter, it does not conclude that the name is insignificant because of the absence of conception. Plausibly this is because the absence is in the hearer, not the speaker.

${ }^{56}$ This passage does not fit the pattern I described earlier, of Hobbes talking as if he held an idea theory only when explicitly stating that theory. I believe I must simply admit this is evidence against my claim, but it is only one passage that does not fit the pattern.
} 
understand Hobbes's argument in this way, then again we must say that it will not persuade his opponents.

The example of "accidents of bread in cheese" concerns the possibility of one instance of an accident inhering first in one object, then in another. Hobbes elsewhere argues against those he thinks have a mistaken conception of accidents. ${ }^{57}$ In Leviathan I.V, Hobbes focuses on the idea that accidents can exist without the substances to which they usually belong. There are philosophers who think that accidents can sometimes exist apart from substances: those who believe that in transubstantiation the substances of the bread and wine are eliminated, and the accidents that before inhere in those substances afterwards either exist without inhering in anything, or inhere only in extended quantity, not in substance. Hobbes criticizes transubstantiation, and we might take his criticism of those who believe accidents to be parts to be directed at those who believe in transubstantiation, or at least at those who explain it by saying that accidents, like parts, do not have to continue to be connected to the substances they are connected to. ${ }^{58}$ Hobbes argues that that we should not treat accidents as capable of existing apart from bodies. Talk about accidents being in bodies should not be taken too literally. If accidents were in bodies "as part in whole or as content in container (contentum in continente) or as householder in house" then they would be bodies themselves. ${ }^{59} \mathrm{~A}$ thing can be in a body only as a part or as a smaller enclosed object, such as the householder. An accident is not in a body in either of these ways, and we should not think of an as like a small body, attaching itself first to one larger body, then another. None of what Hobbes says about accidents and transubstantiation is in any central way connected to signification. Hobbes wants to dissuade people of a mistaken metaphysical belief, not to persuade them that their terms are insignificant. In Leviathan 5.5 the point is presented in terms of signification, the opposing view being said to be meaningless nonsense. But that is not what Hobbes says when he spells out his reasons. There - as when he talks about the insignificance of 'immaterial substance' - the semantic presentation of the objection appears more like a rhetorical flourish than an extra reason.

\footnotetext{
${ }^{57}$ Hobbes, De Corpore 3.4, 8.2.

${ }^{58}$ For his criticisms of transubstantiation, see Leviathan IV.XLIV, 337-8.

${ }^{59}$ Hobbes, De Corpore, 8.3, 8.21.
} 
The other notable examples in Leviathan 5 concern free will. Again, the arguments for Hobbes's view must be sought elsewhere: in this case, in his dispute with Bramhall. ${ }^{60}$ In the Questions Concerning Liberty, Necessity, and Chance, Hobbes argues that insignificant language is used in theories that involve (non-compatibilist) free will: "the defending of this opinion hath drawn the Bishop and other patrons of it into many inconvenient and absurd conclusions, and made them make use of an infinite number of insignificant words". ${ }^{61}$ Hobbes argues that 'rational will' is insignificant - unless it means "a will after deliberation, whether he that deliberateth reasoneth right or not" - as are 'necessary effects' - unless it means "such effects as shall necessarily be produced" - 'free cause', and 'determining themselves' ${ }^{62}$ Hobbes's talk about insignificance in the Questions tends to be in the parts written in the 1650s, rather than in the parts that reproduce texts from his debate with Bramhall in the 1640s. Every use of 'insignificant' is in either the Introduction or in the Animadversions to Bramhall's earlier reply to Hobbes, though there is some talk of what words signify in the earlier texts. So though the Questions shows us some arguments about insignificant speech in a text other than Leviathan, they are from the same period. In the passages in which Hobbes claims that names are insignificant, the claims of insignificance are not Hobbes's main arguments. For example, at one point there is a long discussion of the necessity of causes, with the point about the insignificance of 'free cause' and 'determining themselves' added at the end. ${ }^{63}$ The discussion in which 'rational will' is said to be insignificant is structured in the same way. ${ }^{64}$ The claim about the insignificance of 'necessary effects' comes at the start not the end of the passage it occurs in, but is again not the focus of the discussion. ${ }^{65}$ When Hobbes claims in the Questions that some name is insignificant, that claim functions as an extra accusation about the topic in question, not Hobbes's main argument. This approach resembles that underlying his arguments about insignificant names

\footnotetext{
${ }^{60}$ On that debate, see N.D. Jackson, Hobbes, Bramhall and the Politics of Liberty and Necessity: A Quarrel of the Civil Wars and Interregnum (Cambridge: Cambridge University Press, 2007).

${ }^{61}$ EW 5.18.

${ }^{62}$ EW 5.234, 5.378, 5.404.

${ }^{63}$ EW 5.404.

${ }^{64}$ EW 5.234.

${ }^{65}$ EW 5.378
} 
in Leviathan, which rest on substantive claims about the topics in question, and seem to be rhetorical flourishes on top of those substantive claims.

\section{Hobbes's strategy}

Hobbes's approach can seem curious. If we take the views about insignificance to be supposed to support non-linguistic views - say if we take the insignificance of 'immaterial substance' to support materialism - the approach seems circular. The materialism supports the claim about insignificance, and the claim about insignificance supports the materialism. It is hard to think that Hobbes would not have noticed this. That supports the thought that the insignificant speech arguments are more like rhetorical flourishes than attempts to give reasons. But can we say more about what Hobbes was trying to do by offering arguments with no hope of persuading his opponents (not just because of their intransigence)?

My reading has something common with Engel's discussion of the "Table of Absurdity" in De Corpore ${ }^{66}$ In that table, Hobbes classifies certain sorts of sentences as absurd. It summarizes his view that "copulated names do not cohere in seven ways". ${ }^{67}$

1. If the name of a Body [is copulated] with the name of an Accident.

2. If the name of a Body [is copulated] with the name of a Phantasm.

3. If the name of a Body [is copulated] with the name of a Name

4. If the name of an Accident [is copulated] with the name of a Phantasm.

5. If the name of an Accident [is copulated] with the name of a Name.

6. If the name of a Phantasm [is copulated] with the name of a Name.

7. If the name of a Thing [is copulated] with the name of a Speech [Act]. ${ }^{68}$

Any sentence in one of these categories is supposed to be absurd, just because of the sorts of names in the subject and predicate positions. But as Engel observes "two facts about Hobbes's Table - its place in the line of his argument and its obvious limitations - seem to suggest that the Table arose out of nonlinguistic considerations and was meant to serve an extra-linguistic purpose" ${ }^{69}$ Engel finds a host of non-semantic, non-linguistic arguments

\footnotetext{
${ }^{66}$ S.M. Engel, "Hobbes's Table of Absurdity” Philosophical Review, 70 (1961), 533-43.

${ }^{67}$ Hobbes, De Corpore, 5.2.

${ }^{68}$ Hobbes, De Corpore, 5.2.

${ }^{69}$ Engel, "Hobbes's Table of Absurdity", 537.
} 
being used to support the claims of absurdity. This leads him to much the same worry about circularity that I had above. ${ }^{70}$

Engel's resolution of the lies in thinking that Hobbes's fundamental aim was not really to show something about language and absurdity. The talk about language and absurdity is rather an attempt to support some philosophical theses (not about language).

[W] hat Hobbes really wished to do was not to prove some new thesis about language, but rather to lend added strength to a position already established by subsuming it under some general logical linguistic scheme. For Hobbes's line of argument does not proceed from language to the body of his philosophy, but from the body of his philosophy to certain facts about language which tend, he thinks, to lend support to that body. The ultimate appeal is philosophical, not linguistic. $^{71}$

Something similar, with regard to the direction of argument, is true of the arguments I have been looking at in Leviathan and the Questions concerning Liberty, Necessity, and Chance. In the table of absurdity, Engel sees Hobbes "subsuming it [the position] under some general linguistic scheme". That is not what he's doing in the other texts. Rather, his argument is more like 'in addition, your terminology is insignificant'. Often that will not give further reasons to believe Hobbes, because the reasons to believe the insignificance claim are tied up with the reasons to believe his other claims.

Hobbes is not in such cases subsuming his views under a "linguistic scheme". He is bringing a wide variety of criticisms together as instances of the criticism of others' insignificant speech. There is no unifying theory, but a unifying critical line. Criticisms of views about the nature of the mind, about free will, and about transubstantiation are all brought together, having in common that there is insignificant speech involved. Being able to unify his criticisms in this way helps Hobbes. He can produce lists of insignificant terms his opponents use, creating the appearance of a repeated mistake, despite the reasons for the insignificance of each term being different. Presenting these all as problems about signification allows for a thematic connection to other criticisms of language. Hobbes

\footnotetext{
${ }^{70}$ Engel, "Hobbes's Table of Absurdity", 542.

${ }^{71}$ Engel, "Hobbes's Table of Absurdity", 542.
} 
criticizes opponents for erring by treating words as names that are not really so, ${ }^{72}$ and for confusing people by using Greek or Latin words rather than vernacular ones, and odd invented Latin words at that. ${ }^{73}$ Much of his biblical criticism focuses on the signification of terms, ${ }^{74}$ and some of his moral philosophy does too. ${ }^{75}$ In Leviathan in particular, Hobbes made the problematic language of his opponents a key target of his attacks. ${ }^{76}$ The use of insignificant speech arguments allowed him to collect yet more views under the heading of problematic language, and to make them the targets of such attacks.

\section{Conclusion}

Hobbes's talk about the signification of names can appear confused, but a pattern emerges. When Hobbes presents a theory of names' signification, he takes them to signify ideas. Early on, he held a straightforward idea theory. Later he came to think that names alone did not signify anything, only utterances did. However, he allowed for a secondary sense in which names did signify, in the context of those utterances. Again this was an idea theory, though a more complex one. Outside those theory-stating contexts, Hobbes almost always used 'signify' as if he held an object theory of name signification.

That ambiguity extends into the arguments Hobbes gives against insignificant names in Leviathan. Most of them depend on the object theory, but one hinges on the idea theory. Both sorts of argument are unlikely to be persuasive to Hobbes's opponents, and the claims of insignificance rest upon Hobbes's substantive conclusions about the topics in question. Hobbes liked to add the accusation of insignificance to his other criticisms. But the argument for insignificance does not stand alone in a way that allows it to work as, say, an independent argument for materialism. Rather, arguments for insignificance provided a way for Hobbes to

\footnotetext{
${ }^{72}$ Leviathan IV.XLVI, 372.

${ }^{73}$ Leviathan I.IV, 17; I.VIII, 39.

${ }^{74}$ Leviathan III.XXXII-XXXIX.

${ }^{75}$ Leviathan II.XXI, 107. See Q. Skinner, “Thomas Hobbes on the Proper Signification of Liberty" Transactions of the Royal Historical Society Fifth Series 40 (1990), 121-151.

${ }^{76}$ Hobbes did not give up such criticisms later: see Behemoth's discussion of the universities' use of Aristotelian language. T. Hobbes, Behemoth or The Long Parliament, reprint of the 1889 edition by F. Tönnies with a new Introduction by Stephen T. Holmes (Chicago: IL: University of Chicago Press, 1990), 41-4.
} 
unify various criticisms, and to assimilate his criticism of immaterial substance to his repeated line of attack in Leviathan, that his opponents abused language. 